DOI: $10.17951 / 1 r p .2020 .40 .1 .129-142$

\author{
MAgda URBAŃSKA \\ Uniwersytet Rzeszowski \\ ORCID - 0000-0001-6967-6605
}

\title{
MEDIACJA W SPRAWACH NIELETNICH - WYMIAR WYCHOWAWCZY
}

\begin{abstract}
Streszczenie: Wprowadzenie: Jednym ze sposobów rozwiązywania konfliktów są mediacje, w trakcie których strony dążą, przy pomocy mediatora, do osiągnięcia obopólnie korzystnego porozumienia. Mediacja znajduje swoje zastosowanie także w kontekście spraw karnych, których sprawcami są nieletni. W wyniku mediacji mogą zostać wypracowane satysfakcjonujące obie strony warunki zadośćuczynienia i naprawienia wyrządzonej szkody. Stwarza to szanse na wychowawcze oddziaływanie na młodzież łamiącą normy prawne. Cel badań: W artykule dokonano analizy literatury przedmiotu $\mathrm{z}$ zakresu mediacji karnych oraz aktów prawnych dotyczących mediacji w sprawach nieletnich, skupiając się na ukazaniu specyfiki mediacji z udziałem nieletnich sprawców czynów karalnych oraz korzyściach wychowawczych związanych z prowadzeniem postępowania mediacyjnego w tego rodzaju sprawach. Stan wiedzy: Literatura przedmiotu zwraca uwagę na liczne korzyści związane z prowadzeniem mediacji w sprawach nieletnich, podkreślając zwłaszcza jej wymiar wychowawczy i pozytywny wpływ na rozwój osobowości młodego człowieka. Udział w spotkaniu mediacyjnym pozwala bowiem nie tylko na osiągnięcie satysfakcjonującego porozumienia, ale także, dzięki dobrowolnym i samodzielnym decyzjom podejmowanym przez młodego sprawcę $\mathrm{w}$ trakcie mediacji, na zmianę swojego postępowania w kierunku pożądanym społecznie. Podsumowanie: Mediacja jako sposób rozwiązywania sporów będących wynikiem czynu karalnego pozwala na wypracowanie porozumienia w kwestii zadośćuczynienia i naprawienia przez sprawcę wyrządzanych przez niego krzywd. Ze względu na wychowawczy potencjał mediacji warto byłoby propagować jej szersze wykorzystanie w pracy z młodzieżą, w tym z nieletnimi sprawcami czynów karalnych.
\end{abstract}

Słowa kluczowe: mediacja, nieletni sprawca, porozumienie, zadośćuczynienie 


\section{WPROWADZENIE}

Od wielu lat na świecie, także w Polsce, trwa dyskusja o sposobie traktowania młodych ludzi, którzy złamali prawo i popełnili przestępstwo. Jednym z elementów tej dyskusji jest dylemat dotyczący sposobu reakcji społecznej na złamanie norm prawnych przez nieletniego - po jednej stronie sytuując karę i odpłatę za czyn (sprawiedliwość retrybutywna), po drugiej zaś naprawienie krzywd i zadośćuczynienie osobie pokrzywdzonej (sprawiedliwość naprawcza). W ujęciu sprawiedliwości naprawczej przestępstwo jest uważane za czyn jednej osoby wobec drugiej, a nie atak przeciwko państwu i to właśnie ofiary i sprawcy są tutaj na pierwszym planie (Consedine, 2004). Sprawiedliwość naprawcza skupia się zatem na naprawieniu krzywd wyrządzonych przestępstwem, co znajduje swoje odzwierciedlenie $\mathrm{w}$ działaniach naprawczych podjętych przez sprawcę $\mathrm{z}$ równoczesnym aktywnym włączeniem się do procesu wzajemnych ustaleń także osoby poszkodowanej (Wright, 1999). W procesie reakcji na przestępstwo, oprócz ofiary i sprawcy, uczestniczy także społeczeństwo, które tworzy im jak najkorzystniejsze warunki do naprawy (Consedine, 2004). Właśnie w ten nurt reakcji społecznej na złamanie norm prawnych przez młodego człowieka wpisuje się instytucja mediacji prowadzona pomiędzy nieletnim sprawcą czynu karalnego a osobą poszkodowaną przy udziale mediatora. Mediacja umożliwia bezpośrednie spotkanie sprawcy z poszkodowanym oraz dostrzeżenie, jakie skutki w postaci krzywdy, straty lub szkody zostały wyrządzone niewłaściwym zachowaniem. Sprzyja to realizacji celów wychowawczych wobec nieletniego, przyczyniając się do osiągnięcia korzystnych zmian w osobowości, ucząc konstruktywnego rozwiązywania konfliktów bez użycia przemocy oraz przyjmowania odpowiedzialności za swoje postępowanie.

\section{PROBLEM I CEL BADAŃ}

$\mathrm{W}$ artykule dokonano analizy literatury przedmiotu z zakresu mediacji karnych oraz aktów prawnych dotyczących mediacji w sprawach nieletnich, skupiając się na ukazaniu specyfiki mediacji z udziałem nieletnich sprawców czynów karalnych oraz korzyściach wychowawczych dla sprawcy związanych z prowadzeniem postępowania mediacyjnego $\mathrm{w}$ tego rodzaju sprawach. Problematyka artykułu koncentruje się wokół odpowiedzi na pytania: Co to jest mediacja w sprawach nieletnich? Jakie są przesłanki i przeciwwskazania do kierowania spraw nieletnich do mediacji? Jakie są wymagania wobec instytucji i osób prowadzących mediacje w sprawach nieletnich? Jakie są zasady mediacji w sprawach nieletnich? Jak przebiega spotkania mediacyjne $\mathrm{w}$ sprawach nieletnich? W czym przejawia 
się wychowawczy wymiar mediacji z udziałem nieletniego sprawcy? $\mathrm{W}$ ostatnim wymienionym obszarze odniesiono się do mediacji jako środka realizacji celów wychowawczych wobec nieletniego sprawcy czynów karalnych oraz do korzyści, które za pomocą mediacji może uzyskać młody człowiek, mając równocześnie szansę na zmianę swojego zachowania w kierunku pożądanym społecznie.

\section{STAN WIEDZY}

Prowadzenie mediacji w sprawach nieletnich jest możliwe od 2001 roku na podstawie znowelizowanej w 2000 roku Ustawy z dnia 26 października 1982 r. o postępowaniu w sprawach nieletnich. Mediacja może być wykorzystywana jako środek wychowawczy stosowany wobec młodych ludzi, którzy naruszyli normy prawne, poprzez dopuszczenie się czynu karalnego, lub którzy wykazują przejawy demoralizacji, do których zalicza się: naruszanie zasad współżycia społecznego, popełnienie czynu zabronionego, uchylanie się od obowiązku szkolnego, używanie alkoholu i innych środków służących odurzaniu, nierząd, włóczęgostwo, działalność w grupach przestępczych (Ustawa, 1982). Sam termin „nieletni” odnosi się do osób zdemoralizowanych do 18. roku życia oraz osób, które pomiędzy 13. a 17. rokiem życia dopuściły się czynu karalnego, a także osób do 21. roku życia, wobec których zostały orzeczone środki wychowawcze lub poprawcze (Ustawa, 1982).

W kontekście spraw karnych związanych z przekroczeniem norm prawnych pod pojęciem mediacji jest rozumiana „każda procedura, ze sprawą której ofiara i przestępca mają możliwość, pod warunkiem swobodnie wyrażonej zgody, aktywnego uczestnictwa w rozwiązywaniu problemów wynikających z przestępstwa przy pomocy neutralnej trzeciej strony (mediatora)" (Rekomendacja, 1999, I). Mediacja stanowi „proces zmierzający do ugody pomiędzy sprawcą a pokrzywdzonym, którego celem jest zadośćuczynienie pokrzywdzonemu" (Wajerowska-Oniszczuk, 2012, s. 4). Mediacja umożliwia stronom konfliktu, którymi są poszkodowany i sprawca, samodzielne jego rozwiązanie i wzięcie odpowiedzialności za wynik końcowy (Pawlak, 2014). W zaproponowanej przez Ministerstwo Sprawiedliwości definicji mediacja w sprawach nieletnich jest dobrowolnym i poufnym sposobem rozwiązywania sporów, powstałych w wyniku czynu karalnego, na drodze porozumiewania się pokrzywdzonego i nieletniego sprawcy, przy pomocy bezstronnego i neutralnego mediatora (Ministerstwo Sprawiedliwości (a)). Celem mediacji w sprawach nieletnich jest zadośćuczynienie bądź naprawienie szkody osobie, która jej doświadczyła, a także możliwość pojednania pokrzywdzonego i sprawcy (Suchorska, 2015). 
Sąd rodzinny może skierować sprawę do mediacji z inicjatywy lub za zgodą pokrzywdzonego i nieletniego (Ustawa, 1982). Mediacja może dotyczyć wszystkich czynów karalnych, których dopuścili się nieletni. Do mediacji kierowane są zwłaszcza sprawy, których istotne okoliczności nie budzą wątpliwości (Rozporządzenie, 2001). Literatura przedmiotu wskazuje także, iż sprawa może być kierowana do mediacji, gdy dotyczy czynów karalnych, również tych uznanych za przejaw demoralizacji, oraz gdy istnieje pokrzywdzony; w sprawach, w których strony połączone są stosunkami rodzinnymi, sąsiedzkimi, rówieśniczymi, koleżeńskimi itp.; w sprawach, których podłożem są konflikty międzyludzkie, szczególnie w małych, zamkniętych społecznościach, a także gdy konflikt trwa stosunkowo krótko; ponadto także w przypadku przestępstw incydentalnych, przypadkowych (Rękas, 2009; Suchorska, 2015; Rogozińska, 2019). Podstawą prowadzenia mediacji jest zawsze zgoda pokrzywdzonego i nieletniego sprawcy na wzięcie udziału w postępowaniu mediacyjnym (Sitarz, 2015a).

Jak już wspomniano, mediacja może dotyczyć wszystkich czynów karalnych popełnionych przez nieletnich, jednak praktyka mediacyjna wypracowała kilka przeciwwskazań do kierowania spraw do mediacji. W literaturze przedmiotu wskazuje się tutaj na: negowanie przez sprawcę podstawowych faktów zdarzenia; zaprzeczenie przez nieletniego dopuszczenia się czynu; gdy nie ma pokrzywdzonego; w przypadku upośledzenia umysłowego lub poważnych zaburzeń psychicznych $\mathrm{u}$ jednej lub obu stron; w przypadku spraw związanych z przestępczością zorganizowaną oraz spraw wielowątkowych (Kalisz, Zienkiewicz, 2009; Rękas, 2009; Bieńkowska, 2011; Suchorska, 2015; Sitarz, 2015a; Rogozińska, 2019). Nie powinno się kierować do mediacji spraw, w których sprawca jest zdemoralizowany, posiada niski poziom empatii, jest wielokrotnie karany (Kalisz, Zienkiewicz, 2009; Rękas, 2009). Przeciwwskazaniem może być także postawa pokrzywdzonego wobec sprawcy przejawiająca się nadmierną roszczeniowością, brakiem skłonności do kompromisu, nietolerancyjnością i wrogim nastawieniem (Rękas, 2009; Kalisz, Zienkiewicz, 2009). Za mediacją nie przemawiają także duże nierówności stron w położeniu ekonomicznym lub różnego rodzaju zależności między stronami, co może grozić zaakceptowaniem przez jedną ze stron niekorzystnych warunków ugody (Bieńkowska, 2011; Sitarz, 2015a). Ponadto zwraca się także uwagę, aby do mediacji nie kierować spraw, w których wartość szkody jest wysoka, co związane jest $\mathrm{z}$ tym, że ugoda wypracowana podczas mediacji nie stanowi tytułu egzekucyjnego (Wajerowska-Oniszczuk, 2012).

Zgodnie z Rozporządzeniem Ministra Sprawiedliwości z dnia 18 maja $2001 \mathrm{r}$. $\mathrm{w}$ sprawie postępowania mediacyjnego $\mathrm{w}$ sprawach nieletnich mediacje mogą być prowadzone przez instytucje oraz osoby godne zaufania, które zostały wpisane do wykazu prowadzonego przez prezesa sądu okręgowego. W przypadku instytucji 
są to podmioty, które zgodnie ze swoim statutem realizują zadania $\mathrm{z}$ zakresu mediacji, resocjalizacji, poradnictwa wychowawczego i pomocy psychologicznej, diagnozy psychologicznej, profilaktyki przestępczości oraz ochrony wolności i praw człowieka (Rozporządzenie, 2001). Wymagania formalne są stawiane także samym mediatorom. Mediatorem w sprawach nieletnich może być osoba, która ukończyła 26 lat, korzysta z pełni praw cywilnych i publicznych, włada biegle w mowie i piśmie językiem polskim, a także posiada wykształcenie z zakresu psychologii, pedagogiki, socjologii, resocjalizacji lub prawa oraz ma doświadczenie w zakresie wychowania lub resocjalizacji młodzieży. Mediator w sprawach nieletnich powinien posiadać także umiejętność rozwiązywania konfliktów i nawiązywania kontaktów międzyludzkich. Mediator powinien dawać rękojmię należytego wykonywania obowiązków oraz odbyć szkolenie z zakresu mediacji (Rozporządzenie, 2001).

Ponadto $\mathrm{z}$ uwagi na specyfikę mediacji z udziałem osób nieletnich zostały wskazane osoby, które nie mogą pełnić roli mediatora. Należą do nich: sędziowie, prokuratorzy, asesorzy i aplikanci sądowi lub prokuratorscy, a także osoby pracujące w sądzie, prokuraturze, Policji lub instytucji uprawnionej do ścigania przestępstw, adwokaci, radcy prawni, notariusze asesorzy oraz ich aplikanci, ławnicy sądowi i społeczni kuratorzy sądowi. Mediatorami nie mogą być także komornicy oraz ich aplikanci i pracownicy, funkcjonariusze i pracownicy Służby Więziennej, pracownicy placówek opiekuńczo-wychowawczych, zakładów poprawczych i schronisk dla nieletnich. Mediacji w sprawach nieletnich nie mogą prowadzić pracownicy instytucji bądź członkowie organizacji, które zajmują się działalnością na rzecz ofiar przestępstw (Rozporządzenie, 2001). Ze względu na konieczność zachowania przez mediatora bezstronności mediatorem nie może być osoba powiązana ze sprawą nieletniego, nie może to być zatem np. świadek $\mathrm{w}$ jego sprawie, osoba wydająca opinię na temat nieletniego, osoba sporządzająca wywiad środowiskowy czy prowadząca terapię (Rozporządzenie, 2001).

Mediacja w sprawach nieletnich odwołuje się do głównych zasad mediacji: dobrowolności uczestniczenia stron w mediacji i akceptacji danego mediatora, poufności mediacji, bezstronności i neutralności mediatora oraz jego bezinteresowności (Waszkiewicz, 2009b; Kalisz, Zienkiewicz, 2009; Wajerowska-Oniszczuk, 2012; Sitarz, 2015b). Dobrowolność uczestnictwa stron w mediacji w sprawach karnych wiąże się tutaj ze zgodą na mediację wszystkich jej uczestników, tj. nieletniego sprawcy i jego rodziców lub opiekunów, a także poszkodowanego (w przypadku gdy jest on niepełnoletni zgodę wyrażają również jego rodzice lub opiekunowie), a sama mediacja jest prowadzona $z$ inicjatywy lub za zgodą pokrzywdzonego i nieletniego. Zgoda na mediację może być jednak cofnięta na każdym etapie postępowania mediacyjnego (Rozporządzenie, 2001). Żadna ze stron nie może być przymuszona do mediacji, równocześnie jednak zgoda na uczestnictwo w mediacji może świadczyć na korzyść 
sprawcy i zostać uwzględniona przez sąd (Sitarz, 2015b). Niezwykle ważną zasadą mediacji w sprawach nieletnich jest jej poufność. Wiąże się ona $\mathrm{z}$ uniemożliwieniem osobom postronnym dostępu do informacji, które zostały uzyskane podczas mediacji. Ponadto $\mathrm{w}$ sprawozdaniu $\mathrm{z}$ postępowania mediacyjnego nie mogą być ujęte żadne informacje związane z przebiegiem spotkań mediacyjnych, oceną zachowania uczestników i treścią ich oświadczeń, chyba że uczestnik wyraźnie o to wniesie w odniesieniu do siebie (Rozporządzenie, 2001). Podczas mediacji nie są gromadzone żadne materiały dowodowe dla sądu (Bieńkowska, 2011). Kolejna zasada mediacji w sprawach nieletnich wiąże się z bezstronnością mediatora. Znajduje ona swoje odzwierciedlenie w kilku obszarach, m.in. braku powiązań mediatora z nieletnim oraz jego sprawą, co podkreślają wymogi stawiane mediatorom prowadzącym mediacje w sprawach nieletnich. Dodatkowo bezstronność wyraża się pośrednio także w zakazie prowadzenia mediacji w lokalu zajmowanym przez uczestników mediacji lub ich rodziny, nie można jej także prowadzić w budynku sądu (Rozporządzenie, 2001; Sitarz, 2015b). Bezstronny mediator traktuje obie strony w taki sam sposób, nie przychyla się do racji żadnej ze stron, nie jest stronniczy i nie ocenia stron. Jak zauważa Olga Sitarz, w przypadku mediacji w sprawach nieletnich mediator jest $\mathrm{w}$ szczególnej sytuacji, bowiem uczestnikami postępowania mediacyjnego są osoby, których rola jest niejako z góry zdefiniowana jako „dobra” i „zła”. Mediator nie może jednak oceniać sprawcy i jego czynu. Dodatkowo powinien czuwać, z zachowaniem bezstronności, nad równowagą między stronami, gdyż większe uprawnienia decyzyjne związane ze zgodą na potencjalne ustalenia istnieją po stronie osoby pokrzywdzonej (Sitarz, 2015b). Neutralność mediatora wiąże się z tym, że nie narzuca on stronom żadnego rozwiązania, a jedynymi osobami, które powinny być usatysfakcjonowane ugodą, są wyłącznie uczestnicy mediacji. Wzajemne ustalenia stron, które zostały zapisane w ugodzie, są analizowane jedynie w kontekście ich zgodności z prawem i zasadami współżycia społecznego (Sitarz, 2015b).

W sytuacji gdy sąd rodzinny skieruje sprawę do mediacji, w pierwszej kolejności mediator nawiązuje kontakt $\mathrm{z}$ uczestnikami mediacji, tj. nieletnim i jego rodzicami oraz poszkodowanym (i jego rodzicami, gdy jest on osobą niepełnoletnią), jak również odbiera od nich zgodę na mediację i przeprowadza indywidualne spotkania informacyjne dotyczące istoty mediacji, jej zasad oraz roli i uprawnień uczestników. Kolejnym etapem jest wspólne spotkanie mediacyjne wszystkich uczestników, w trakcie którego mediator pomaga w sformułowaniu ugody między pokrzywdzonym a sprawcą, a także sprawdza wykonanie zobowiązań wynikających z zawartego porozumienia. Ostatnim etapem jest sporządzenie przez mediatora sprawozdania, w którym jest informacja m.in. o wynikach postępowania mediacyjnego, do którego jest dołączona ugoda - jeśli została ona zawarta (Rozporządzenie, 2001; Rogozińska, 2019). 
Warto jednak zwrócić uwagę, że ustawodawca dopuszcza możliwość prowadzenia mediacji w sposób pośredni - nie w formie bezpośredniego spotkania nieletniego sprawcy z pokrzywdzonym, zastrzega jednak, że jest to możliwe tylko wtedy, gdy względy oddziaływania wychowawczego na nieletniego nie stoją temu na przeszkodzie (Rozporządzenie, 2001). Jest to bardzo ważne, gdyż dzięki bezpośredniej mediacji nieletni sprawca osobiście konfrontuje się z konsekwencjami swego czynu, czego istotnym elementem jest właśnie spotkanie z konkretną osobą poszkodowaną (Waszkiewicz, 2009a). Barbara Wajerowska-Oniszczuk nazywa takie bezpośrednie spotkanie "najlepszą lekcją w życiu nieletniego” (Wajerowska-Oniszczuk, 2012, s. 10), gdyż jego konsekwencje mogą mieć doniosłe znaczenie w kontekście kształtowania osobowości młodego człowieka oraz profilaktyki przestępczości.

W literaturze przedmiotu zwraca się uwagę na liczne korzyści związane z mediacją jako sposobem rozwiązywania konfliktów pomiędzy nieletnim sprawcą a poszkodowanym, podkreślając szczególnie wymiar wychowawczy mediacji wobec nieletniego. Dzięki mediacji młody człowiek ma bowiem szansę, aby uświadomić sobie, że naruszył normę prawną, jaką krzywdę i szkodę wyrządził oraz jakie są tego konsekwencje dla konkretnego poszkodowanego. W trakcie mediacji ma możliwość przeproszenia, zaproponowania osobie pokrzywdzonej zadośćuczynienia za doznane krzywdy. Mediacja może stanowić także szansę na pojednanie stron lub poprawę wzajemnych relacji (Nadzieja-Maziarz, 2014; Pawlak, 2014; Suchorska, 2015; Szczepanik, Jaros, Staniaszek, 2018). Spotkanie mediacyjne może przyczynić się do zakończenia konfliktu pomiędzy pokrzywdzonym a sprawcą poprzez wspólne porozumienie się w kwestii zadośćuczynienia i naprawienia szkód. Warto jednak podkreślić, że sprawca nie jest tutaj podmiotem, któremu pokrzywdzony ma wymierzyć sprawiedliwość. Celem ich spotkania jest zrozumienie przez sprawcę skali krzywd, których doznał pokrzywdzony w wyniku jego działań oraz świadoma i dobrowolna zgoda na ich naprawienie (Skorupski, 2009).

Samodzielnie i zaproponowane $\mathrm{z}$ własnej woli przez młodego człowieka zobowiązanie do naprawienia szkody oraz dobrowolne i świadome przeprosiny to największy sukces wychowawczy mediacji. Jest to szczególnie ważne zwłaszcza w przypadku młodych ludzi, uczy ich bowiem przyjmowania odpowiedzialności za swoje czyny (Czarnecka-Dzialuk, 2014; Pawlak, 2014; Nadzieja-Maziarz, 2015; Suchorska, 2015; Szczepanik, Jaros, Staniaszek, 2018; Rogozińska, 2019). Renata Szczepanik, Agnieszka Jaros i Magdalena Staniaszek zwracają także uwagę na wychowawczy walor mediacji w kontekście uczenia zarządzania emocjami i nazywania uczuć, co pomaga budować świadomość samego siebie, przyczyniając się w ten sposób do rozwoju osobowości młodego człowieka (Szczepanik, Jaros, Staniaszek, 2018). 
Mediacja dostarcza narzędzi do wynagrodzenia krzywd, strat i szkód, ma na celu pozytywną zmianę osobowości, co jest szansą na uniknięcie stygmatyzacji w środowisku (Rogozińska, 2019). Agnieszka Rogozińska wskazuje, że dzięki mediacji pojawia się szansa na wzmocnienie relacji nieletniego zachowującego się w sposób niepożądany społecznie ze społecznością szkolną, co może zapobiegać zjawisku naznaczenia społecznego i jego wiktymizacji (Rogozińska, 2019). Jest to więc szansa na powrót do normalnego życia (Waszkiewicz, 2009a). Mediacja sprzyja także rozwijaniu świadomości etycznej i moralnej młodzieży oraz pozwala na funkcjonowanie w relacjach, które są wolne od przemocy (Rogozińska, 2019).

Wychowawczego oddziaływania mediacji można upatrywać także w kontekście udziału rodziców nieletniego w postępowaniu mediacyjnym. Ważne jest jednak, by nie zdominowali swojego dziecka podczas spotkania mediacyjnego, ale pozostawili mu na pełną autonomię w zakresie ustalania warunków zadośćuczynienia. Chodzi tutaj bowiem o wzięcie przez nieletniego odpowiedzialności za swój czyn oraz samodzielne zaproponowanie rekompensaty, a także późniejszą realizację przez nieletniego wspólnych ustaleń będących wynikiem ugody mediacyjnej. $\mathrm{W}$ tym przejawia się bowiem pełne uczestnictwo $\mathrm{w}$ mediacji - $\mathrm{w}$ bezpośrednim kontakcie pokrzywdzonego i sprawcy oraz ich wspólnych, odpowiedzialnych decyzji (Waszkiewicz, 2009a). Rodzice powinni pełnić raczej rolę obserwatorów, choć formalnie to właśnie oni wyrażają zgodę na podpisanie ugody w przypadku zadośćuczynienia finansowego lub rzeczowego (Nadzieja-Maziarz, 2015; Sitarz, 2015b; Rogozińska, 2019). Pozostawienie dziecku możliwości wskazania własnych propozycji działań naprawczych byłoby tym samym także szansą dla rodziców na rozwijanie własnych umiejętności wychowawczych i przejawem odpowiedzialności za wychowanie dziecka.

W literaturze przedmiotu zwraca się uwagę, że niekiedy nieletni wyrażają zgodę na mediację, gdyż w ich przekonaniu pozwoli im to na uniknięcie prawnych konsekwencji czynu. Jednak po bezpośrednim spotkaniu z osobą poszkodowaną, która opowiada o swoich rzeczywistych stratach, krzywdzie i emocjach więżących się z czynem nieletniego, motywacja ta może ulec zmianie w kierunku zrozumienia, jakie faktycznie zostały wyrządzone szkody i przyjęcia odpowiedzialności za swoje działanie. Znajduje to swoje odzwierciedlenie właśnie w propozycjach zadośćuczynienia szkody (Waszkiewicz, 2009a; Gruca-Miąsik, 2011; Wajerowska-Oniszczuk, 2012). Jak zauważa Barbara Wajerowska-Oniszczuk, taka bezpośrednia konfrontacja sprawcy z poszkodowanym ma wielki walor wychowawczy, wpływając na zmiany w osobowości nieletniego sprawcy znacznie skuteczniej niż inne środki wychowawcze stosowane przez sądy w sprawach nieletnich (Wajerowska-Oniszczuk, 2012). Sam fakt, że sprawca dobrowolnie przeprosi pokrzywdzonego, co uzgodnił samodzielnie podczas spotkania mediacyjnego, może być pozytywnym 
doświadczeniem dla obu stron i mieć większe znaczenie, niż gdyby takie same przeprosiny nakazał sąd.

W wymiarze praktycznym zawarcie przez sprawcę ugody może przyczynić się do zmniejszenia lub złagodzenia kary oraz zapobiec stygmatyzacji jako osoby karanej, a także dalszej demoralizacji (Pawlak, 2014). Sąd uwzględnia pozytywny wynik mediacji, choć nie jest związany treścią ugody. Jeśli sąd uzna, że za pomocą mediacji zostały osiągnięte cele wychowawcze, może umorzyć postępowanie, może także dobrać odpowiednie środki wychowawcze i powiązać je z mediacją, by pełniły funkcje zadośćuczynienia. Mediacja może także wpływać na zmianę lub uchylenie wykonywanego środka wychowawczego bądź też na warunkowe zwolnienie czy warunkowe zawieszenie umieszczenia $\mathrm{w}$ zakładzie poprawczym (Kalisz, Zienkiewicz, 2009; Lewicka, Grudziewska 2010; Bieńkowska, 2011). Stwarza to tym samym korzystniejsze warunki dla resocjalizacji sprawcy (Pawlak, 2014). W tym kontekście warto także zwrócić uwagę, że nieletni biorący udział w mediacji rzadziej wracają na drogę przestępstwa. $Z$ badań ewaluacyjnych eksperymentalnego programu mediacji w sprawach nieletnich prowadzonego w Polsce w latach 1996-1999 wynika, że tylko niewielka część osób, których sprawy skierowano do mediacji w ramach tego programu w okresie do 10 lat od jego zakończenia, weszło ponownie $\mathrm{w}$ konflikt $\mathrm{z}$ prawem. Część $\mathrm{z}$ osób, które ponownie złamały normy prawne, dopuściło się pojedynczych, drobnych czynów. Wychowawczy wpływ mediacji na nieletniego podkreślali badani sędziowie rodzinni i kuratorzy sądowi; dodatkowo sędziowie rodzinni wskazywali, że nieletni biorący udział w mediacji najczęściej nie powracają do sądu (Czarnecka-Dzialuk, 2014).

Mimo wielu korzyści związanych $\mathrm{z}$ udziałem w mediacji przez nieletniego sprawcę sądy rodzinne niezbyt chętnie sięgają po ten środek wychowawczy. Z badań różnych autorów, przytaczanych przez Renatę Szczepanik, Agnieszkę Jaros i Magdalenę Staniaszek, wynika, że barierami w przekazywaniu spraw do mediacji są nieufność sądów do instytucji mediacji w sprawach nieletnich, niedoskonałe regulacje prawne $\mathrm{w}$ tym obszarze, a także problemy $\mathrm{z}$ kwalifikacją spraw do mediacji oraz nawyki sądów w orzekaniu środków wychowawczych. Dodatkowo kierowaniu spraw do ugodowego rozwiązania nie sprzyja brak popularności idei mediacji oraz sprawiedliwości naprawczej wśród sędziów i całego społeczeństwa (Szczepanik, Jaros, Staniaszek, 2018). Przekłada się to na niewielką ilość mediacji ze skierowania sądu, np. w 2014 roku do mediacji z zakresu prawa karnego skierowanych zostało $0,16 \%$ spraw (Rudolf i in., brw). Również liczba spraw związanych $\mathrm{z}$ nieletnimi skierowanymi do mediacji jest raczej niewielka: w 2002 roku takich spraw było 40, w 2003 - 60, w 2004 - 254, w 2005 - 343, w 2006 - 244, w 2007 - 325, przy czym większość z nich zakończyła się ugodą (Rękas, 2009). $\mathrm{Z}$ analizy danych, przeprowadzonej przez Agnieszkę Lewicką i Ewę Grudziew- 
ską na podstawie danych z 79 losowo wybranych sądów rejonowych, wynika, że w latach 2003-2007 w toku postępowania mediacyjnego rozwiązywano 778 spraw z udziałem nieletnich, co stanowiło $0,42 \%$ ogółu tego rodzaju spraw. Największą grupe spraw kierowanych do mediacji stanowiły sprawy zakwalifikowane do przestępstw przeciwko życiu i zdrowiu (248 spraw) oraz sprawy o demoralizację (201 spraw). Niezwykle wysoki był za to odsetek spraw zakończonych ugodami $(84,83 \%)$ (Lewicka, Grudziewska, 2010). Aktualne dane Ministerstwa Sprawiedliwości wskazują, że w 2015 roku skierowano do mediacji 212 spraw nieletnich, spośród których 155 postępowań zakończyło się ugodą. W 2018 roku mediacji w sprawach nieletnich było już 360 , z czego w 270 przypadkach zostały podpisane ugody. W pierwszej połowie 2019 roku prowadzono 189 postępowań mediacyjnych, z których 78\% zakończyło się ugodą (Ministerstwo Sprawiedliwości (b); Ministerstwo Sprawiedliwości, 2019).

\section{PODSUMOWANIE}

Mediacja w sprawach nieletnich to specyficzny rodzaj mediacji, w której uczestniczą nieletni sprawca czynu karalnego oraz osoba poszkodowana. Przy pomocy bezstronnego i neutralnego mediatora, dobrowolnie, z zachowaniem zasady poufności rozwiązują oni spór będący wynikiem czynu karalnego, porozumiewając się co do sposobu zadośćuczynienia, który byłby zadowalający dla obu stron. Rozwiązywanie konfliktów pomiędzy pokrzywdzonym a sprawcą na drodze mediacji nie jest jednak sytuacją częstą w praktyce postępowania z nieletnimi sprawcami czynów karalnych. Mimo iż sukcesywnie zwiększa się liczba postępowań mediacyjnych, mediacja nadal wydaje się rzadko wykorzystywana do osiągania korzystnych zmian w zachowaniu i osobowości nieletniego sprawcy. Z kolei literatura przedmiotu wskazuje na olbrzymi potencjał wychowawczy mediacji. Dzięki mediacji młody człowiek, który dopuścił się czynu karalnego ma szansę na bezpośrednią konfrontację z osobą, która została pokrzywdzona jego czynem, może dostrzec negatywne skutki swojego zachowania w życiu konkretnej osoby, zetknąć się z jej emocjami, stratą i krzywdą. W trakcie mediacji obie strony mogą wspólnie ustalić sposób zadośćuczynienia i naprawienia wyrządzonej krzywdy, który będzie zgodny z ich potrzebami. W przypadku nieletniego sprawcy jest to szczególnie ważne, gdyż uczy się on przyjmowania odpowiedzialności za swoje czyny oraz samodzielnego podejmowania decyzji. Mediacja to także szansa na świadome wyrażenie przeprosin wobec drugiego człowieka oraz dobrowolne zobowiązanie do naprawienia wyrządzonej krzywdy. W tym wymiarze mediacja może przyczyniać się więc do realizacji celów wychowawczych wobec nieletniego. 


\section{WNIOSKI}

Mediacja z udziałem osoby nieletniej i pokrzywdzonego, prowadzona przy pomocy bezstronnej osoby trzeciej, pozwala na rozwiązanie konfliktu, który powstał w wyniku czynu karalnego i wypracowanie, na drodze wzajemnych ustaleń, satysfakcjonującego obie strony porozumienia w postaci zadośćuczynienia pokrzywdzonemu i naprawienia jego krzywd. Młody człowiek, który naruszył normy prawne, ma szansę na przyjęcie odpowiedzialności za swoje naganne zachowanie, biorąc równocześnie aktywny udział w całym procesie dochodzenia do obopólnie zadowalającego porozumienia. Bezpośrednie spotkanie się nieletniego sprawcy z człowiekiem pokrzywdzonym jego czynem może spowodować przemianę w zachowaniu i stać się szansą na dobrowolne przeprosiny oraz świadome działania restytucyjne, wynikające $z$ wewnętrznej potrzeby naprawienia krzywdy (Lewicka-Zelent, 2013). Mediacja sprzyja zatem wychowawczemu oddziaływaniu na młodego człowieka wchodzącego w konflikty z prawem, stając się również alternatywnym, wobec sądu, sposobem reagowania na społecznie szkodliwe zachowania młodzieży. Warto byłoby zatem zwiększyć zainteresowanie mediacją poprzez intensyfikację działań na rzecz popularyzowania wśród społeczeństwa idei sprawiedliwości naprawczej oraz ugodowego rozwiązywania konfliktów bez użycia przemocy.

\section{LITERATURA}

Bieńkowska, E. (2011). Mediacja w sprawach nieletnich. Stan prawny na 1 września 2011 r. Warszawa: Ministerstwo Sprawiedliwości.

Consedine, J. (2004). Sprawiedliwość naprawcza. Przywrócenie ładu społecznego. Warszawa: Polskie Stowarzyszenie Edukacji Prawnej.

Czarnecka-Dzialuk, B. (2014). Profilaktyczne aspekty sprawiedliwości naprawczej - prezentacja wyników badań nieletnich uczestników mediacji. W: M. Plucińska (red.). Rozwiazywanie sytuacji konfliktowych $w$ wymiarze jednostkowym i społecznym (s. 275-284). Poznań: Wyd. Naukowe Wydziału Nauk Społecznych Uniwersytetu im. A. Mickiewicza.

Gruca-Miąsik, U. (2011). Negocjacje i mediacje w kręgu pomocy, wychowania i prawa. Rzeszów: Wyd. UR.

Kalisz, A., Zienkiewicz, A. (2009). Mediacja sądowa i pozasądowa. Zarys wykładu. Warszawa: Wolters Kluwer.

Lewicka, A., Grudziewska, E. (2010). Mediacja sądowa. Alternatywna metoda resocjalizacyjna? Lublin: Wyd. UMCS. 
Lewicka-Zelent, A. (2013). Uwarunkowania gotowości nieletnich do zadośćuczynienia w paradygmacie sprawiedliwości naprawczej. Lublin: Wyd. UMCS.

Meier, B.-M. (1999). Sprawiedliwość naprawcza - zarys koncepcji. W: B. Czarnecka-Dzialuk. D. Wójcik (red.). Mediacja. Nieletni przestępcy i ich ofiary (s. 39-65). Warszawa: Oficyna Naukowa.

Ministerstwo Sprawiedliwości (2019). Postępowania w sprawach nieletnich (rodzinnych) $\mathrm{w}$ sądach powszechnych zakończone w wyniku postępowania mediacyjnego w latach 2004-I półrocze 2019 r. Źródło: https://isws.ms.gov.pl/pl/baza-statystyczna/ opracowania-wieloletnie/ [dostęp: 3.12.2020].

Ministerstwo Sprawiedliwości (a). Informacja o postępowaniu mediacyjnym w sprawach nieletnich. Źródło: https:/www.gov.pl/web/sprawiedliwosc/postepowanie-mediacyjne-w-sprawach-nieletnich3 [dostęp: 19.11.2020].

Ministerstwo Sprawiedliwości (b). Mediacje w sprawach nieletnich w latach 2004-2015. Źródło: www.gov.pl/web/sprawiedlwosc/dane-statystyczne-dotyczace-mediacji [dostęp: 19.11.2020].

Nadzieja-Maziarz, A. (2015). Aspekt wychowawczy mediacji z sprawach z nieletnim sprawcą czynu karalnego. W: T. Rakoczy (red.). Przyszłość mediacji w polskim systemie prawa (s. 61-69). Lublin: Wyd. KUL.

Pawlak, B. (2014). Mediacja w sprawach z nieletnim sprawcą czynu karalnego na przykładzie praktyki w Apelacji łódzkiej. W: M. Plucińska (red.). Rozwiązywanie sytuacji konfliktowych w wymiarze jednostkowym i społecznym (s. 365-373). Poznań: Wyd. Naukowe Wydziału Nauk Społecznych Uniwersytetu im. A. Mickiewicza.

Rekomendacja Nr R (99) 19 Komitetu Ministrów [Rady Europy] dla Państw Członkowskich o mediacji w sprawach karnych (przyjęta przez Komitet Ministrów 15 września 1999 r. na 679 posiedzeniu przedstawicieli Ministrów i Komentarz). Źródło: https://www.gov.pl/web/sprawiedliwosc/miedzynarodowe-i-polskie-standardy-dotyczace-mediacji [dostęp: 15.11.2020].

Rękas, A. (2009). Rozwój mediacji w Polsce - zagadnienia prawne i praktyczne.

W: D. Czura-Kalinowska (red.). Mediacja i arbitraż jako sposoby polubownego rozstrzygania sporów (s. 55-68). Poznań: Wyższa Szkoła Pedagogiki i Administracji. Rogozińska, A. (2019). Praktyczne aspekty zawodu mediatora. Poradnik. Warszawa: Difin. Rozporządzenie Ministra Sprawiedliwości z dnia 18 maja 2001 r. w sprawie postępowania mediacyjnego (Dz. U. Nr 56, poz. 591).

Rudolf, A., Cichowicz-Major, M., Matysiak, M., Pałka, S., Pieniążek W., Przybył, C. (brw). Diagnoza stanu stosowania mediacji oraz przyczyn zbyt niskiej w stosunku do oczekiwanej popularności mediacji. Raport końcowy (brw). Źródło: http://docplayer.pl/18813209-Raport-koncowy-diagnoza-stanu-stosowania-mediacji-oraz-przyczyn-zbyt-niskiej-w-stosunku-do-oczekiwanej-popularnosci-mediacji. html [dostęp: 20.11.2020]. 
Sitarz, O. (2015a). Mediacja w sprawach karnych. W: O. Sitarz (red.). Metodyka pracy mediatorów w sprawach karnych (s. 79-175). Warszawa: Difin.

Sitarz, O. (2015b). O mediacji w ogólności. W: O. Sitarz (red.). Metodyka pracy mediatorów w sprawach karnych (s. 25-38). Warszawa: Difin.

Skorupski, W. (2009). Racjonalnie o mediacji. W: M. Leśniak (red.). Mediacja w rozwiązywaniu konfliktów wieku adolescencji (s. 51-67). Kraków: Krakowska Akademia im. Andrzeja Frycza Modrzewskiego.

Suchorska, A. (2015). Mediacja w postępowaniu z nieletnimi jako niewykorzystany środek wychowawczy ustawy o postępowaniu w sprawach nieletnich. W: P. Malinowski. H. Duszka-Jakimko. A. Suchorska (red.). Wokół praktycznych i teoretycznych aspektów mediacji (s. 153-166). Kraków: Uniwersytet Opolski.

Szczepanik, R., Jaros, A., Staniaszek, M. (2018). Sąd nad demoralizacją nieletnich. Konteksty wychowawcze. Łódź: Wyd. UŁ.

Ustawa z dnia 26 października 1982 r. o postępowaniu w sprawach nieletnich (Dz. U. z 1982, Nr 35, poz. 228 z późn. zm.).

Wajerowska-Oniszczuk, B. (2012). Mediacja w polskim prawie nieletnich. Stan prawny na 1 grudnia 2012 r. Warszawa: Ministerstwo Sprawiedliwości.

Waszkiewicz, P. (2009a). Mediacja w sprawach nieletnich. W: E. Gmurzyńska. R. Morek (red.). Mediacje. Teoria i praktyka (s. 219-229). Warszawa: Wolters Kluwer.

Waszkiewicz, P. (2009b). Zasady mediacji. W: E. Gmurzyńska. R. Morek (red.). Mediacje. Teoria i praktyka (s. 91-105). Warszawa: Wolters Kluwer.

Wright, M. (1999). Geneza i rozwój sprawiedliwości naprawczej. W: B. Czarnecka-Dzialuk. D. Wójcik (red.). Mediacja. Nieletni przestępcy i ich ofiary (s. 14-38). Warszawa: Oficyna Naukowa.

\title{
MEDIATION IN JUVENILE CASES - EDUCATIONAL ASPECT
}

\begin{abstract}
Introduction: One way of resolving conflicts is through mediation, in which the parties seek a mutually beneficial agreement reached with the help of a mediator. Mediation may also be used in criminal cases involving minors as perpetrators. Mediation can lead to agreeing conditions of the compensation and redress for the harm done which are satisfactory to both parties. This creates opportunities for educating young people who violate legal standards. Purpose: This article provides an analysis of the literature dealing with criminal mediation and legal acts concerning mediation in cases involving minor perpetrators. It focuses on showing the specifics of mediation targeted to minor law offenders and the educational benefits of mediation in such cases. State of knowledge: Professional literature concerning the subject matter draws attention to numerous benefits of mediation in cases involving minor offenders, emphasising in particular its educational aspect and its positive impact on the
\end{abstract}


development of the personality of the young person. It is so because participation in a mediation meeting allows not only to reach a mutually satisfactory agreement, but also thanks to voluntary and independent decisions made by young offenders during such meetings, they have a chance to change their behaviour as desired by the society. Summary: Mediation as disputes resolution method applied to disputes arising from a criminal act makes it possible to reach an agreement concerning the compensation and redress for the harm done by the perpetrator. Due to the educational potential of mediation, its wider use in work with young people, including minor law offenders, would be worth propagating.

Keywords: agreement, compensation, juvenile offender, mediation 